\title{
Pulmonary vascular permeability to transferrin in the pulmonary oedema of renal failure
}

\author{
G M ROCKER, A G MORGAN, D PEARSON, G S BASRAN, D J SHALE
}

From the Respiratory Medicine Unit, University of Nottingham, and the Renal Unit and Department of Medical Physics, City Hospital, Nottingham

ABSTRACT Thirteen patients with renal failure and pulmonary oedema were assessed for evidence of increased pulmonary vascular permeability to protein by a double isotope technique. Com-

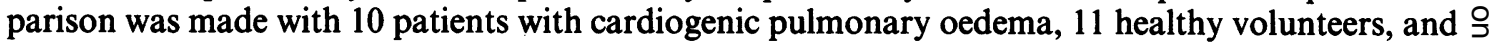
10 patients with the adult respiratory distress syndrome. There was no significant difference in the $\rightarrow$ accumulation of a radiolabelled plasma protein (transferrin) in patients with renal or cardiogenic pulmonary oedema and normal volunteers. Patients with adult respiratory distress syndrome $\frac{}{6}$ showed significantly greater protein permeability $(p<0.001)$. In pulmonary oedema associated with renal failure managed by current regimens there was no evidence of increased permeability to transferrin.

The mechanisms underlying the pulmonary oedema of renal failure are unknown, but fluid overload, left ventricular failure, and increased pulmonary microvascular permeability secondary to uraemia have all been invoked. There is increased endothelial permeability to sodium and water in pulmonary oedema, including that associated with renal failure, ${ }^{1}$ and alveolar epithelial permeability to technetium-99m labelled diethylenetriamine pentacetic acid $\left({ }^{99 m} \mathrm{Tc}\right.$ DTPA, 492 daltons) was increased before and reduced during haemodialysis. ${ }^{2}$

Histological studies of uraemic lung showed the presence of a proteinaceous oedema fluid but many of the subjects had intra-alveolar haemorrhage. ${ }^{3}$ Direct sampling of oedema fluid by endotracheal aspiration in two patients showed a raised protein content, suggesting increased pulmonary vascular permeability to plasma proteins in renal failure ${ }^{4}$ although the lack of change in the volume of distribution for albumin in the lung suggests the opposite. ${ }^{1}$

To investigate the possibility that increased vascular permeability to plasma protein occurs in pulmonary oedema associated with renal failure, we determined the accumulation of radiolabelled transferrin in the lung. Patients with renal and cardiac failure associated pulmonary oedema were compared with healthy controls and patients with high permeability pulmonary oedema.

Address for reprint requests: Dr D J Shale, Respiratory Medicine Unit, City Hospital, Nottingham NG5 IPB.

Accepted 18 February 1987

\section{Methods}

\section{SUBJECTS}

We studied 23 patients with pulmonary oedema-13 with renal failure and 10 with left ventricular failure after myocardial infarction or excessive postoperative fluid replacement (tables 1.and 2). Pulmonary oedema was diagnosed according to standard clinical and radiological criteria (dyspnoea and the finding of crackles on auscultation, alveolar shadowing with or $\dot{0}$ without effusions, and pulmonary venous con- 3 . gestion). Transferrin accumulation in these patients $\delta$ was compared with that in 11 healthy volunteers (10 non-smokers) and 10 patients with the adult respiratory distress syndrome, where evidence of increased microvascular permeability would be expected. ${ }^{5}$ The diagnosis of adult respiratory distress syndrome was made according to the standard criteria ${ }^{6}$ of an 5 accepted risk factor, no prior lung disease or evidence $\tilde{O}$ of left ventricular failure, bilateral multiple lobe $\underset{\omega}{N}$ involvement on the chest radiograph, and an arterial $\sigma$ oxygen tension to inspired oxygen concentration ratio

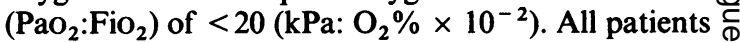
with adult respiratory distress syndrome had histo- $\stackrel{?}{+}$ logical evidence at necropsy of diffuse alveolar dam- $T$ age; and all of them required intermittent positive 0

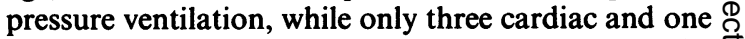
renal patient needed ventilation. The study had the $\mathbb{\mathbb { D }}$ approval of the local ethical committee and informed consent was obtained from all subjects or their closest relative if appropriate. 
Table 1 Details of 13 patients with renal failure and pulmonary oedema

\begin{tabular}{|c|c|c|c|c|c|c|c|c|}
\hline $\operatorname{Age}(y)$ & Sex & $\operatorname{Urea}(\mathrm{mmol} / \mathrm{l})$ & Creatinine ( $\mu \mathrm{mol} / \mathrm{l})$ & $\begin{array}{l}\text { Duration renal } \\
\text { failure ( } \mathrm{mo})\end{array}$ & Dialysis treatment & $A l b(g / l)$ & $\begin{array}{l}\text { Total protein } \\
(\mathbf{g} / \mathbf{l})\end{array}$ & $\frac{\mathrm{PaO}_{2}}{\mathrm{FiO}_{2}}$ \\
\hline $\begin{array}{l}45 \\
49 \\
30 \\
54 \\
68 \\
63 \\
33 \\
62 \\
38 \\
33 \\
27 \\
32 \\
68\end{array}$ & $\begin{array}{l}\mathrm{F} \\
\mathrm{M} \\
\mathrm{M} \\
\mathrm{M} \\
\mathrm{F} \\
\mathrm{F} \\
\mathrm{M} \\
\mathrm{F} \\
\mathrm{M} \\
\mathrm{M} \\
\mathrm{M} \\
\mathrm{M} \\
\mathrm{M}\end{array}$ & $\begin{array}{l}25 \cdot 4 \\
31.8 \\
27.5 \\
31.9 \\
33 \cdot 1 \\
31 \cdot 8 \\
31.6 \\
16 \cdot 2 \\
46.7 \\
39 \cdot 1 \\
35 \cdot 3 \\
23.8 \\
61.0\end{array}$ & $\begin{array}{r}* \\
* \\
565 \\
859 \\
275 \\
474 \\
682 \\
420 \\
980 \\
583 \\
960 \\
1373 \\
1045 \\
1308\end{array}$ & $\begin{array}{r}0 \\
0 \\
37 \\
10 \\
77 \\
63 \\
0 \\
51 \\
34 \\
0 \\
37 \\
57 \\
0\end{array}$ & $\begin{array}{l}\text { HD } \\
\overline{H D} \\
\mathrm{HD} \\
\overline{-} \\
\overline{-} \\
\overline{C A P D} \\
\overline{-} \\
\text { CAPD } \\
\text { CAPD }\end{array}$ & $\begin{array}{l}25 \\
15 \\
33 \\
24 \\
25 \\
29 \\
16 \\
27 \\
32 \\
32 \\
26 \\
15 \\
22\end{array}$ & $\begin{array}{l}62 \\
49 \\
67 \\
50 \\
- \\
46 \\
56 \\
51 \\
70 \\
45 \\
60\end{array}$ & $\begin{array}{l}25 \cdot 0 \\
47 \cdot 8 \\
47 \cdot 1 \\
38 \cdot 7 \\
- \\
\overline{29} \cdot 3 \\
40 \cdot 9 \\
58 \cdot 9 \\
\overline{-} \\
\overline{31} \cdot 5 \\
48 \cdot 0\end{array}$ \\
\hline $\begin{array}{l}\text { Mean } \\
\text { SD }\end{array}$ & & $\begin{array}{l}33 \cdot 5 \\
11 \cdot 1\end{array}$ & $\begin{array}{l}794 \\
350\end{array}$ & & & $\begin{array}{r}24 \cdot 7 \\
6 \cdot 3\end{array}$ & $\begin{array}{r}55.6 \\
8.8\end{array}$ & $\begin{array}{l}40 \cdot 8 \\
10 \cdot 9\end{array}$ \\
\hline
\end{tabular}

*Result invalid-bilirubin $>1000 \mu \mathrm{mol} / \mathrm{l}$. HD—haemodialysis; CAPD—continuous ambulatory peritoneal dialysis; Pao ${ }_{2}$-arterial oxygen tension; $\mathrm{FiO}_{2}-$ fractional inspired oxygen $\left(\mathrm{PaO}_{2} / \mathrm{FiO}_{2}\right.$ is the arterial oxygen $(\mathrm{kPa})$ divided by the inspired oxygen in $\left.\%{ }^{-2}\right)$.

Table 2 Details of 10 patients with left ventricular failure after myocardial infarction or excessive fluid replacement

\begin{tabular}{|c|c|c|c|c|}
\hline $\operatorname{Age}(y)$ & Sex & $\operatorname{Alb}(g / l)$ & Total protein $(\mathrm{g} / \mathrm{l})$ & $\frac{\mathrm{PaO}_{2}}{\mathrm{FiO}_{2}}$ \\
\hline $\begin{array}{l}39 \\
54 \\
24 \\
67 \\
52 \\
19 \\
69 \\
59 \\
59 \\
28\end{array}$ & $\begin{array}{l}\mathbf{M} \\
\mathbf{M} \\
\mathbf{F} \\
\mathbf{F} \\
\mathbf{M} \\
\mathbf{M} \\
\mathbf{M} \\
\mathbf{M} \\
\mathbf{M} \\
\mathbf{M}\end{array}$ & $\begin{array}{l}\frac{34}{25} \\
\frac{33}{22} \\
24 \\
\frac{29}{30}\end{array}$ & $\begin{array}{l}\frac{63}{78} \\
\frac{45}{57} \\
\frac{57}{68} \\
70\end{array}$ & $\begin{array}{r}- \\
\overline{15} \cdot 7 \\
35 \cdot 0 \\
15 \cdot 6 \\
8 \cdot 3 \\
24 \cdot 0 \\
22 \cdot 7 \\
37 \cdot 3 \\
27 \cdot 3\end{array}$ \\
\hline $\begin{array}{l}\text { Mean } \\
\text { SD }\end{array}$ & & $\begin{array}{r}28 \cdot 1 \\
4 \cdot 6\end{array}$ & $\begin{array}{l}63 \cdot 5 \\
11 \cdot 5\end{array}$ & $\begin{array}{r}23 \cdot 2 \\
9.9\end{array}$ \\
\hline
\end{tabular}

\section{DOUBLE ISOTOPE TECHNIQUE}

Pulmonary accumulation of protein was determined by a double isotope method, ${ }^{7}$ modified and described in detail by Basran et al. ${ }^{8}$ In this technique increased permeability to protein is detected by accumulation of transferrin (labelled in vivo with indium-113m $(20 \mathrm{MBq})$ ) by comparison with an intravascular control marker (red blood cells labelled in vivo with technetium ${ }^{99} \mathrm{~m}$ Tc $(12 \mathrm{MBq})$ ). In vivo labelling of transferrin with $113 \mathrm{~m} \mathrm{In}$ is highly efficient at 30 minutes ${ }^{9}$ and red blood cell labelling efficiency at 3 hours was $92 \%$ (D Pearson, unpublished data). The radiation dose equivalent for each patient did not exceed $0.2 \mathrm{mSv}$ ( $20 \mathrm{rem}$ ).

External detection of both isotopes from the upper lobe of the lung was compared with external detection from over the heart during a series of 30 second count periods for each site with monitoring for one hour. This was achieved by using a single probe with three fixed lights attached, which allowed accurate repositioning by refocusing the lights on to markings on the chest. For each count period the following ratio was calculated:

$$
\frac{\text { In lung counts }}{\text { In heart counts }} \div \frac{\text { Tc lung counts }}{\text { Tc heart counts }}
$$

A fitted regression line for these data against time was derived. The protein accumulation index (PAI) was numerically equal to the gradient of this line. The ratio of lung to heart counts corrects for radioactive decay, changes in blood volume, and loss of transferrin to other extra vascular compartments. Examples of PAI calculations are given in figure 1.

\section{COLLOID OSMOTIC PRESSURE}

An estimate of colloid osmotic pressure was determined from serum albumin and globulin concentration ${ }^{10}$ for the groups with renal and cardiac disease.

\section{STATISTICS}

Data throughout are expressed as means with standard deviations in parentheses. The significance of differences between groups was assessed by analysis of variance. All PAI values given are the higher measurement if a bilateral study was performed.

\section{Results}

The mean PAI of the patients with renal failure was not significantly different $(p>0.05)$ from that of the cardiac group or a healthy control group. The mean PAI values for all three groups were significantly lower than for the adult respiratory distress syndrome group ( $p<0.001$ ) (fig 2 ). The mean arterial oxygen tension ratio for the cardiac group was significantly less than that of the renal group $(p<0.01$; tables 1 and 2 ) and that of the patients with adult respiratory distress syndrome (mean 13.2 (SD 3.4)) was 


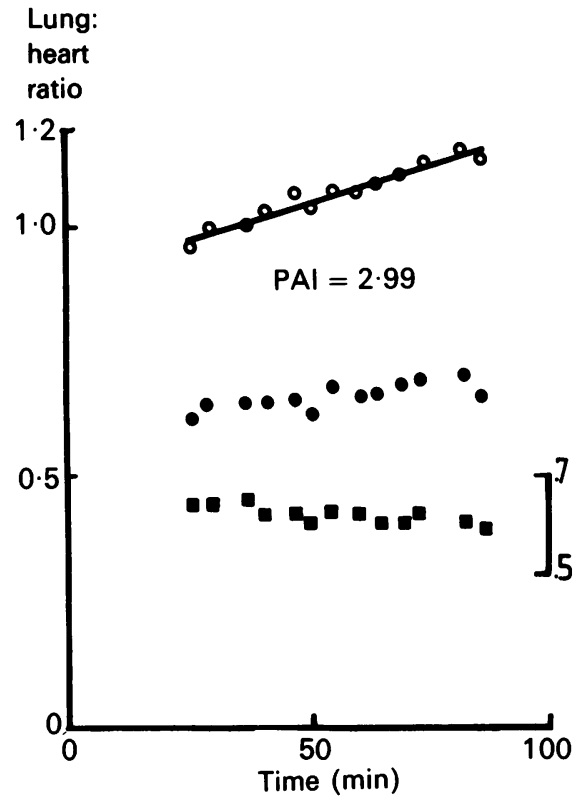

(a)

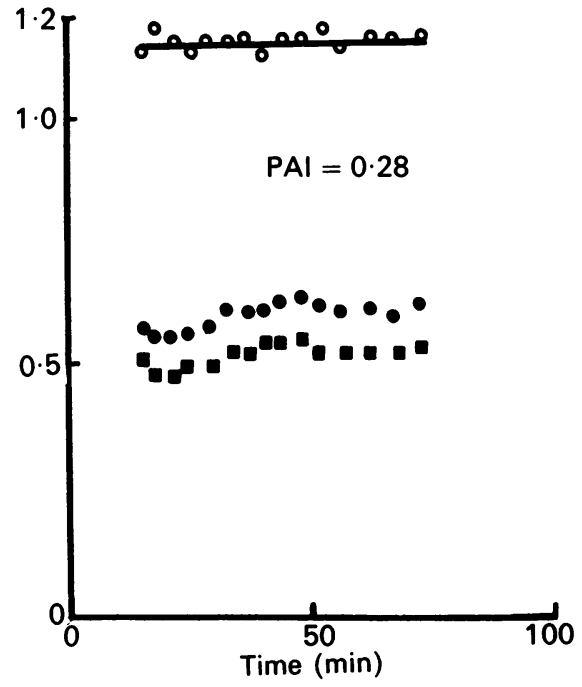

(b)

LVF

Fig 1 Derivation of a protein accumulation index (PAI) from protein and red blood cell counts in patients with adult respiratory distress syndrome (ARDS) (a) and left ventricular

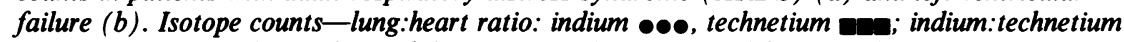
ratio: 000. PAI is the gradient of the regression line computed for the indium:technetium ratio. To avoid overlap technetium counts from the patients with adult respiratory distress syndrome have been lowered with the ratio axis to the right.

PAI

$$
{ }_{-1}^{6}
$$

Normal

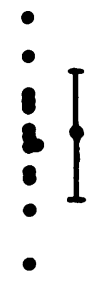

Renal

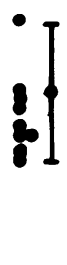

Cardiac

significantly less than both these groups (cardiac; $\mathrm{p}<0.001$; renal: $\mathrm{p}<0.001$ ). The mean total protein and albumin concentrations were similar (tables 1$)$ and 2) and the mean (SD) calculated colloid osmotic $\frac{}{2}$ pressures were not significantly different (221(57) $\mathrm{cmH}_{2} \mathrm{O}$ for renal and $277(52) \mathrm{cm} \mathrm{H}_{2} \mathrm{O}$ for cardiac patients).

The pulmonary capillary wedge pressures that were available from two patients with renal disease ( 20 and $26 \mathrm{mmHg}$ ) and four with cardiac disease (mean 20 은 (SD 4.3) $\mathrm{mm} \mathrm{Hg}$ ) were consistent with the devel- $\rightarrow$ opment of hydrostatic oedema.

\section{Discussion}

A common feature of pulmonary oedema is increased permeability to water and low molecular weight solutes, probably attributable to haemodynamic factors and associated hydration of the alveolar interstitium $\mathbb{D}$ and basement membrane. ${ }^{1112}$ In renal failure there is ${ }^{+}$ additional evidence suggesting increased pulmonary ${ }^{\circ}$ microvascular permeability to protein. The main evi- $\frac{}{\mathbb{D}}$ dence comes from histological studies of patients with $\stackrel{\Omega}{\longrightarrow}$ uraemic lung. The alveoli of patients with this com- $\stackrel{\mathbb{Q}}{\Omega}$ plication of end stage untreated renal failure appeared to be filled with proteinaceous fluid. ${ }^{31314}$ Additional support comes from a study of two crit-응 ically ill patients with severe pulmonary oedema,

Fig 2 Protein accumulation index (PAI) in pulmonary oedema of renal, cardiac, and non-cardiac origin (adult respiratory distress syndrome-ARDS) compared with healthy normal controls. Individual results are given plus the mean and standard deviation for each group. 
renal failure, and hypertension in whom the colloid osmotic pressures of the pulmonary oedema fluid were similar to those of serum, implying increased permeability to protein. ${ }^{4}$ The clinical features in these patients were similar to those reported earlier in patients with uraemic lung.

In the study reported here there was no evidence of increased pulmonary endothelial permeability to the plasma protein transferrin ( 75000 daltons) in patients with pulmonary oedema associated with renal or cardiac failure. In neither group was permeability to transferrin significantly different from that of healthy control subjects. This is consistent with an unchanged lung albumin space reported in renal failure patients with pulmonary oedema. ${ }^{1}$ The patients with adult respiratory distress syndrome in this study, however, showed increased protein accumulation, which is consistent with other studies using this double isotope technique. 89 Animal studies show that this technique is sensitive and specific for lung disorder of the adult respiratory distress syndrome type when compared with hydrostatic pulmonary oedema. ${ }^{15}$ In the renal group two subjects (Nos 1 and 11, table 1) had PAI values similar to those in the group with adult respiratory distress syndrome. Patient 1 had a positive blood culture, but neither patient met criteria for adult respiratory distress syndrome at the time of the study or afterwards. Both the patients with cardiac disease who had raised PAI values were studied after myocardial infarction and one had received several DC conversions for dysrrhythmias in the preceding 24 hours, which may have affected pulmonary vascular permeability.

It is possible that the severe complication known as uraemic lung is not the same as the pulmonary oedema currently seen in renal failure. In a series of five such cases all were uraemic with severe hypertensive cardiac failure and blood pressures of 180-300 $\mathrm{mm} \mathrm{Hg}$ systolic and 130-160 $\mathrm{mm} \mathrm{Hg}$ diastolic. ${ }^{3}$ Hypertension was a prominent feature of other similar studies. ${ }^{13141617}$ In the patients studied here systolic pressures were $80-220 \mathrm{~mm} \mathrm{Hg}$ and diastolic pressures $40-130 \mathrm{~mm} \mathrm{Hg}$ and only five patients were considered to be hypertensive. Uraemic lung may have resulted from a combination of hypertension and severe left ventricular overload, leading to the production of a protein rich pulmonary oedema due to secondary permeability changes and intra-alveolar haemorrhage.

Thus in pulmonary oedema associated with renal failure managed under current regimens there is no increased pulmonary vascular permeability to the plasma protein transferrin. The double isotope method may be of use in identifying patients with renal failure and pulmonary oedema due to adult respiratory distress syndrome.
We would like to thank Mrs CB Richards, medical physics technician, for assistance with radioisotope studies and the physicians at the City Hospital, Nottingham, for permission to study patients under their care. This study was supported by a Chest, Heart, and Stroke Association award to DJS and the City Hospital Kidney Fund.

\section{References}

1 Crosbie WA, Snowden S, Parsons V. Changes in lung capillary permeability in renal failure. $\mathrm{Br} \mathrm{Med} J$ 1972;iv:388-90.

2 Belcher NG, Rees PJ. Changes in pulmonary clearance of technetium labelled DTPA during haemodialysis. Thorax 1986;41:381-5.

3 Doniach I. Uremic edema of the lungs. Am J Roentgenol Rad Ther Nucl Med 1947;58:620-8.

4 Rackow EC, Fein IA, Sprung C, Grodman RS. Uremic pulmonary edema. Am J Med 1978;64:1084-8.

5 Sibbald WJ, Anderson RR, Holliday RL, Driedger AA. Alveolo-capillary permeability in human septic ARDS. Chest 1981;79:133-42.

6 Petty TL, Fowler AA. Another look at ARDS. Chest 1982;82:98-103.

7 Gorin AB, Kohler J, DeNardo G. Noninvasive measurement of pulmonary transvascular protein flux in normal man. J Clin Invest 1980;66:869-77.

8 Basran GS, Byrne AJ, Hardy JG. A noninvasive technique for monitoring lung vascular permeability in man. Nucl Med Commun 1985;3:3-10.

9 Braude S, Nolop KB, Hughes JMB, Barnes PJ, Royston D. Comparison of lung vascular distress syndrome. Am Rev Respir Dis 1986;133:1002-5.

10 Keys A. The study of colloidal dimensions, thermodynamic activity and the mean molecular weight of the mixed proteins in blood serum. J Phys Chem 1938;42:11-20.

11 Bauman A, Rothschild MA, Yalow RS, Berson SA. Pulmonary circulation and transcapillary exchange of electrolytes. J Appl Physiol 1957;11:353-61.

12 Lillienfield LS, Freis ED, Partenope EA, Morowitz HJ. Transcapillary migration of heavy water and thiocyanate ion in the pulmonary circulation of normal subjects and patients with congestive heart failure. $J$ Clin Invest 1955;34:1-8.

13 Bass HE, Singer E. Pulmonary changes in uremia. JAMA 1950;144:819-23.

14 Hopps HC, Wissler RW. Uremic pneumonitis. Am J Pathol 1955;31:261-73.

15 Dauber IM, Pluss WT, VanGrondelle A, Trow RS, Weil JV. Specificity and sensitivity of noninavasive measurement of pulmonary vascular protein leak. $J$ Appl Physiol 1985;59:564-74.

16 Rendich RA, Levy AH, Cove AM. Pulmonary manifestations of azotemia. Am J Roentgenol Rad Ther Nucl Med 1941;46:802-8.

17 DePass SW, Stein J, Poppel MH, Jacobson HG. Pulmonary congestion and edema in uremia. $J A M A$ 1956;162:5-9. 